\title{
Metode Pengolahan Darah sebagai Pakan Unggas: Review
}

\author{
Method of Cattle Blood Processing in Producing Powder \\ for Poultry Feed Component: A Review
}

\author{
R. F. Ramadhan, Y. Marlida, Mirzah, dan Wizna \\ Fakultas Peternakan, Universitas Andalas \\ email: fani.rahmad@gmail.com \\ (Diterima: 6 Desember 2014; Disetujui: 2 Februari 2015)
}

\begin{abstract}
ABSTRAK
Darah sapi merupakan limbah hasil ikutan ternak yang dapat dimanfaatkan sebagai bahan pakan penyusun ransum ternak unggas. Darah dapat dimanfaatkan sebagai pakan dalam bentuk tepung. Pembuatan tepung darah dapat dilakukan melalui proses fisik, biologi, dan kombinasi keduanya. Pemanfaatan tepung darah sebagai ransum unggas sangat terbatas, hal ini disebabkan ketidakseimbangan asam amino yang terdapat pada tepung darah. Pemanfaatan tepung darah dapat ditingkatkan dengan cara pengolahan. Metode pengolahan darah dapat dilakukan dengan menggunakan tiga metode yaitu pengeringan, penyerapan dan fermentasi. Metode pengeringan hanya dapat digunakan dalam ransum unggas sebesar 3-6\%, sedangkan metode penyerapan dapat meningkatkan penggunaan tepung darah sebagai pakan ternak menjadi $15 \%$, dan metode fermentasi darah menggunakan mikroorganisme sebagai inokulum dapat memanfaatkan tepung darah sampai $20 \%$ dalam ransum unggas.
\end{abstract}

Kata kunci: tepung darah, metode pengolahan darah, pakan unggas

\section{ABSTRACT}

A kind of slaughterhouse waste is cattle blood which can be used as a feed component of poultry rations, mainly in powder form. While the usage of blood powder is limited due to amino acid imbalance, there is a need of transforming blood of both physically or biologically process to produce blood powder. This effort consequently enhances blood powder benefit. Method of processing cattle blood consisted of three types; drying, absorption and fermentation. Drying method could only be used in poultry rations up to 3-6\%, while the absorption method increased the use of blood powder as poultry feed up to 15\%. Finally, the blood fermentation method using microorganism as inoculums could enhance up to $20 \%$ of blood powder in poultry rations.

Keywords: blood powder, blood processing method, poultry feed

\section{PENDAHULUAN}

Perkembangan usaha peternakan terutama sektor peternakan unggas sangat berkembang pesat, hal ini tidak sepenuhnya didukung dengan ketersediaan pakan. Pakan merupakan biaya produksi tertinggi dalam usaha peternakan unggas, untuk itu perlu dicari bahan pakan yang murah dan tersedia sepanjang tahun yang dapat mengurangi biaya produksi dalam usaha peternakan unggas. Hasil ikutan ternak merupakan limbah yang ketersediaannya sangat berlimpah dan perlu dimanfaatkan sehingga menjadi ramah lingkungan. Tepung darah merupakan hasil ikutan ternak yang memiliki potensi untuk dijadikan bahan pakan sumber protein penyusun ransum ternak karena memiliki kandungan protein yang tinggi yaitu sekitar $80-85 \%$. 
Pemanfaatan tepung darah sebagai pakan unggas sangat terbatas, penggunaannya dalam ransum tidak direkomendasikan lebih dari 5\% (Dafwang et al., 1986), hal ini dikarenakan kecernaan dari tepung darah tidak efisien seperti kecernaan tepung ikan (Haq et al., 2004). Crawshaw (1994) menyatakan keterbatasan penggunaan tepung darah dalam ransum broiler dikarenakan ketidaseimbangan asam amino yang menyebabkan menurunnya performa ternak. Titin (2011) menyatakan tepung darah mengandung zat besi yang cukup tinggi sehingga keberadaannya dapat mengganggu kecernaan dari zat nutrisi lainnya dalam ransum. Tepung darah juga mengandung asam amino terbatas yaitu asam amino isoleusin, yang apabila terjadi kekurangan akan menyebabkan penerunan pertumbuhan bobot badan sehingga juga dapat menurunkan produksi karkas.

Pengolahan tepung darah untuk pakan unggas telah banyak diteliti oleh berbagai peneliti agar dapat meningkatkan penggunaan tepung darah. Pengolahan yang umum dilakukan yaitu dengan metode pengeringan. Metode pengeringan ini hanya dapat memanfaatkan tepung darah sekitar 3-6\% dalam ransum. Selain cara pengeringan, pengolahan tepung darah juga telah dilakukan dengan berbagai metode seperti penyerapan dan fermentasi. Pengolahan tepung darah dengan cara penyerapan biasa dilakukan dengan menyerapkan darah ke dalam limbah industri pertanian agar proses pengeringan lebih mudah, dimana pada metode pembuatan tepung darah dengan cara pengeringan mengalami kendala dalam proses pengeringan sehingga dilakukan metode penyerapan untuk memperpendek waktu pengeringan tepung darah dan juga dapat meningkatkan nilai nutrisi dari limbah.

Pengolahan tepung darah dengan metode fermentasi juga merupakan satu cara pengolahan yang dapat meningkatkan kualitas dari tepung darah dengan memanfatkan aktivitas mikroorganisme untuk merombak zat makanan. Esonu et al. (2011) melakukan fermentasi darah segar dan cairan rumen selama 4 hari dimana pemberian $20 \%$ dalam ransum tidak memberikan pengaruh yang negatif terhadap pertumbuhan broiler finisher. Sementara itu $\mathrm{Xu}$ et al. (2011) mengolah tepung darah dengan cara memfermentasi campuran Rapeseed meal dan tepung darah dengan Lactobacillus plantarum dan Bacillus subtilis sebagai inokulum yang dapat menggantikan bungkil kedelai dalam pakan itik. Proses fermentasi merupakan proses mendayagunakan aktivitas suatu mikroba tertentu atau campuran beberapa spesies mikroba untuk menghasilkan enzim yang dapat memecah suatu senyawa yang komplek menjadi senyawa yang lebih sederhana agar dapat mudah dicerna oleh ternak.

Pada review ini akan dibahas mengenai metode pengolahan dan pemanfaatan tepung darah sebagai pakan ternak.

\section{Tepung Darah}

Darah merupakan hasil ikutan ternak yang dapat dimanfaatkan sebagai sumber protein bagi ternak. Darah dapat dimanfaatkan dalam bahan pakan ternak dalam bentuk tepung darah. Menurut Padmono (2005), tepung darah merupakan bahan pakan ternak yang berasal dari darah segar (sapi, kerbau, kambing dan domba) yang diperoleh dari Rumah Potong Hewan (RPH). Tepung darah telah dilaporkan mengandung protein sekitar $80-85 \%$, variasi dari kandungan tepung darah tersebut disebabkan perbedaan dalam metode pembuatan tepung darah (McDonald et al., 1998). Rasyaf (1994a) melaporkan tepung darah mengandung protein kasar sebesar $80 \%$, lemak $1,6 \%$, serat kasar $1 \%$, tetapi miskin kalium dan phospor. Darah sangat sulit untuk dikeringkan dan merupakan medium yang bagus untuk pertumbuhan mikroba karena kandungan air yang tinggi (Donkoh et al., 1999). Kandungan air darah segar sekitar $80 \%$ dan kandungan air tepung darah sekitar 16,5\% (Setiowati et al., 2014).

Tepung darah kaya akan asam amino lysine, arginine, methionine, cystine, dan leucine tetapi sangat miskin asam amino isoleusine dan mengandung glycine lebih rendah dibandingkan dengan tepung ikan (NRC, 1994). Odukwe dan Njoku (1987) menyatakan tepung darah kaya akan asam 
amino lysine. Dari penelitian yang telah dilakukan sebelumnya suplementasi $1,5 \%$ tepung darah lebih baik dibandingkan suplementasi campuran lysine dan methionine sintetik (Njoku, 1985). Ketika dibandingkan suplementasi tepung darah dengan protein tumbuhan untuk pakan unggas cukup tinggi nilai biologisnya, protein tumbuhan umumnya kekurangan dua asam amino esensial yaitu lysine dan methionine sementara tepung darah kaya akan dua asam amino tersebut (McDonald et al., 1992).

Ketersedian darah sebagai hasil ikutan ternak sangat melimpah. Berdasarkan Badan Pusat Statistik, jumlah pemotongan sapi tahun 2013 di Sumatera Barat mencapai 33.436 ekor dimana setiap pemotongan ternak, darah yang dihasilkan antara 7-9\% dari berat badannya (Santoso, 1989). Jika diasumsikan berat ratarata sapi yang dipotong $200 \mathrm{~kg}$, maka darah yang dihasilkan pertahunnya sebesar 601.848 $\mathrm{kg}$ dimana rasio pembuatan tepung darah berkisar 5:1 yaitu dimana $5 \mathrm{~kg}$ darah segar dapat diperoleh $1 \mathrm{~kg}$ tepung darah (Anuragaja, 2012). Tepung darah yang dapat dihasilkan pertahunnya di Sumatera Barat sekitar $120.370 \mathrm{~kg}$.

\section{Pengolahan tepung darah}

Tepung darah merupakan salah satu bahan pakan alternatif sebagai sumber protein, tetapi pemanfaatannya dalam ransum sangat terbatas sehingga perlu pengolahan untuk meningkatkan pemanfaatannya. Berbagai pengolahan telah dilakukan untuk meningkatkan pemanfaatan tepung darah dalam ransum ternak yaitu dengan cara pengeringan, penyerapan/pencampuran dan fermentasi.

\section{Pengeringan}

Metode pengeringan dapat dilakukan dengan dua cara yaitu dengan cara pengeringan biasa atau melalui pemanasan (vat drying) dan menguapkan air dengan suhu rendah (freeze drying) (Setiowati et al., 2014). Pengolahan darah dengan cara pengeringan ini biasanya dilakukan dengan cara perebusan terlebih dahulu sebelum darah dikeringkan. Perebusan darah ini dapat menyebabkan terdenaturasinya protein, hal ini dikarena perebusan memerlukan suhu yang tinggi yaitu sekitar $80-100^{\circ} \mathrm{C}$. Denaturasi protein mengakibatkan turunnya kelarutan, peningkatan viskositas, hilangnya aktifitas biologi dan protein mudah diserang enzim proteolitik (Oktavia, 2007).

Denaturasi juga menyebabkan protein kehilangan karakteristik struktural dan beberapa kandungan senyawa di dalamnya, namun struktur utama protein seperti $\mathrm{C}, \mathrm{H}, \mathrm{O}$ dan $\mathrm{N}$ tidak akan berubah (Stoker, 2010). Denaturasi yang diakibat oleh perlakuan panas pada protein menyebabkan molekul - molekul yang menyusun protein bergerak dengan sangat cepat sehingga sifat protein yaitu hidrofobik menjadi terbuka. Akibatnya, semakin panas, molekul akan bergerak semakin cepat dan memutus ikatan hidrogen di dalamnya (Vladimir, 2007)

Khawaja et al. (2007) melakukan pengolahan tepung darah dengan cara pengeringan dimana darah terlebih dulu direbus dengan suhu $100^{\circ} \mathrm{C}$ selama 45 menit untuk mengurangi kadar air dan bakteri patogen. Setelah direbus kemudian dikeringkan di oven dengan suhu $55^{\circ} \mathrm{C}$ selama 6 hari dan kemudian digiling. Produk tepung darah yang dihasilkan oleh Khawaja hanya dapat dimanfatkan sebagai bahan pakan penyusun ransum broiler sebesar 3\%. Setiowati et al. (2014) juga telah melakukan pengolahan darah sapi menjadi tepung darah dengan metode pengeringan. Darah segar direbus selama 20 menit dengan suhu $80^{\circ} \mathrm{C}$ dan diaduk rata, kemudian dijemur dibawah sinar matahari dengan ketebalan \pm 1 $\mathrm{cm}$ selama $16 \mathrm{jam}$, lalu di oven dengan suhu $60^{\circ} \mathrm{C}$ selama 2-3 hari dan terakhir digiling hingga menjadi tepung. Dari percobaan yang dilakukan Setiowati, tepung darah sebanyak $4 \%$ merupakan hasil terbaik dari $8 \%$ dan $12 \%$ yang ditambahkan di dalam ransum burung puyuh.

Banyak penelitian yang telah dilakukan menunjukkan perlakuan panas dalam pengolahan bahan pakan sumber protein dapat mengalami penurunan kualitas protein dan menurunkan kecernaan. Penurunan kecernaan asam amino lysine dan histidine yang 
disebabkan oleh panas yang tinggi telah dilaporkan Zhang dan Parsons (1994). Penurunan kecernaan lysine ini dikarenakan pembentukan reaksi maillard yang terjadi selama proses pemanasan (Hurrel,1990). Lysine adalah asam amino esensial yang memiliki gugus amin yang mudah bereaksi dengan gugus karbonil dari gula pereduksi (Nursten, 2005), sehingga pada saat reaksi Maillard terjadi maka ketersediaan lysine berkurang (Pahm et al., 2008). Meskipun kehilangan gula lebih besar dibandingkan kehilangan asam amino (Adrian et al., 1962), tetapi reaksi Maillard dapat menurunan kualitas protein (Adrian, 1974).

Pengolahan tepung darah dengan cara pengeringan memiliki beberapa kendala di dalam proses pengolahannya yaitu pada proses perebusan darah yang memerlukan sugu tinggi sekitar $80-100^{\circ} \mathrm{C}$ yang dapat menyebabkan protein mengalami denaturasi. Pengolahan dengan metode pengeringan juga memiliki kelemahan pada proses pengeringan yang memerlukan waktu yang lama yaitu sekitar 36 hari, hal ini dikarenakan kandungan air tepung darah yang tinggi.

\section{Penyerapan (Pencampuran)}

Metode pengolahan dengan cara penyerapan (pencampuran) merupakan pengolahan yang dilakukan dengan mencampurkan darah dengan limbah pertanian atau dengan limbah hasil ikutan ternak. Sonaiya (1988) menyarankan menggunakan limbah tanaman atau limbah industri pertanian sebagai bahan absorban (penyerap) untuk tepung darah agar meningkatkan luas permukaan sehingga cepat dalam proses pengeringan.

Makinde dan Sonaiya (2011) melakukan pengolahan tepung darah dengan metode penyerapan (pencampuran). Limbah jagung dicampur dengan darah segar (darah dicegah dari pembekuan selama 6 jam dengan menggunakan $18 \mathrm{~g}$ garam/liter darah. Perbandingan limbah jagung dan darah sebesar 1:1 (w/w), kemudian campuran limbah jagung dan darah dikeringkan dengan sinar matahari selama 3-4 jam, dicampur lagi dengan darah (5:4 w/w) dan digiling dalam bentuk tepung setelah kering. Penggunaan campuran limbah jagung dan darah ini dalam ransum ayam broiler dapat digunakan sebesar $15 \%$ untuk broiler starter dan finisher. Makinde dan Sonaiya $(2007,2010)$ telah melaporkan prosedur sederhana dalam mengoptimalisasi pencampuran limbah tanaman dan darah, dimana prosedur pencampuran ini dapat mempercepat proses pengeringan darah dengan sinar matahari ( $<4$ hari), meningkatkan protein kasar dari limbah jagung dan dapat mengurangi pencemaran lingkungan dari limbah Rumah Potong Hewan (RPH).

Odunsi (2003) telah melakukan pencampuran darah sapi dengan cairan rumen untuk menggantikan bungkil kacang tanah dan tepung ikan dalam ransum ayam petelur. Darah segar dan cairan rumen ditimbang dengan rasio perbandingan $1: 1$, kemudian dicampurkan dan direbus selama 90 menit sambil diaduk agar tercampur merata. Selanjutnya campuran darah dan cairan rumen dijemur di bawah sinar matahari sampai kandungan airnya mencapai $15 \%$, kemudian digiling. Pada penelitian ini, penggunaan campuran darah dan cairan rumen sebagai bahan pakan tidak mendukung sepenuhnya dalam meningkatkan performa jika dibandingkan dengan ransum yang tanpa pemberian tepung darah. Penambahan campuran darah dan cairan rumen dalam menggantikan tepung ikan memberikan respon performa yang lebih bagus daripada menggantikan bungkil kacang tanah. Penambahan tepung darah dan atau cairan rumen telah dilaporkan (Donkoh et al., 1999; Abubakar dan Yusuph, 1991) dapat memberikan bau yang buruk terhadap ransum sehingga mengurangi palatabilitas yang mengakibatkan penurunan konsumsi dan selanjutnya menurunkan performa broiler (Dongmo et al., 2000; Emmanuel, 1978).

Onyimongi dan Ugwu (2007) melakukan pencampuran kulit singkong dengan darah sapi dengan perbandingan $1: 1 ; 1: 2 ; 1: 3$; 2:1; dan 3:1 untuk menggantikan 50\% bungkil kedelai. Darah sapi segar dan kulit singkong ditimbang sesuai dengan perbandingan pencampuran, kemudian dicampurkan dan diaduk hingga merata. Campuran di rebus selama 30 menit pada suhu $75-80^{\circ} \mathrm{C}$ dan dijemur. 
Kandungan protein kasar meningkat dengan semakin tingginya komposisi darah, sementara kandungan protein menurun dengan perbandingan komposisi kulit singkong yang tinggi. Kecenderungan peningkatan protein tersebut dikarenakan tepung darah memiliki protein yang tinggi. Komponen serat kasar menurun dengan peningkatan fraksi tepung darah, dan sebaliknya jika peningkatan fraksi kulit singkong maka komponen serat kasar meningkat. Dari percobaan yang dilakukan Onyimongi dan Ugwu pakan broiler starter yang mengandung berbagai variasi perbandingan kulit singkong dengan darah sapi efektif meningkatkan pertumbuhan broiler, namun dari analisis ekonominya perbandingan campuran kulit singkong dan darah sapi 1:3 memberikan keuntungan ekonomi yang optimum.

Pengolahan tepung darah menggunakan metode penyerapan (pencampuran) lebih baik dibandingkan dengan pengolahan tepung darah menggunakan metode pengeringan, hal ini dapat dilihat dari meningkatnya pemanfaatan tepung darah sampai $15 \%$ dalam ransum unggas yang diolah dengan metode penyerapan. Pengolahan tepung darah dengan cara penyerapan ini juga dapat mempercepat proses pengeringan yang dapat mempersingkat waktu pembuatan tepung darah dan juga dapat meningkatkan kualitas nutrisi dari limbah pertanian yang digunakan sebagai bahan penyerap darah.

\section{Fermentasi}

Pengolahan tepung darah dengan metode fermentasi biasanya dilakukan dengan menyerapkan atau mencampurkan darah dengan limbah pertanian atau limbah rumah potong hewan dengan menggunakan mikroorganisme sebagai inokulum dan difermentasi sesuai dengan keadaan optimal yang dapat meningkatkan aktivitas mikroba. Fermentasi membutuhkan biaya yang sedikit dan dapat meningkatkan bioavailability nutrisi dengan meningkatkan kecernaan nutrisi ternak (Esonu et al., 2011).

Esonu et al. (2011) melakukan fermentasi campuran darah sapi dengan cairan rumen yang dicampur dengan perbandingan 1:3 dan kemudian dilanjuti dengan fermentasi selama 4 hari. Kemudian dikeringkan dibawah sinar matahari 3-4 hari tergantung intensitas sinar matahari. Fermentasi campuran darah sapi dan cairan rumen dibumbui dengan bubuk kari untuk menutupi bau tak sedap. Campuran digiling hingga menjadi bentuk tepung dan dicampurkan dalam ransum sebesar 5, 10, 15 dan 20\%. Hasil percobaan menunjukkan penambahan fermentasi campuran darah dan cairan rumen pada level $10 \%$ dilaporkan memiliki konsumsi pakan dan pertambahan berat badan yang paling tinggi pada broiler finisher. Peningkatan performa broiler yang mengandung fermentasi campuran darah dan cairan rumen bisa dikaitkan dengan kandungan protein yang tinggi yaitu sebesar $29,86 \%$. Peningkatan ini juga bisa disebabkan pengaruh protein mikroba, pati tercerna dan karbohidrat berserat, asam lemak rantai panjang dan sebagian protein tercerna dari bahan percobaan (Esonu et al., 2006; Okorie, 2005; Ekwuoma, 1992; Whyte dan Wadak, 2002; Aganga, 1985 dan Odunsi, 2003).

$\mathrm{Xu}$ et al. (2011) melakukan Fermentasi Rapeseed Meal (FRSM) untuk menggantikan bungkil kedelai pada ransum itik. $75 \%$ rapeseed meal dicampur dengan 25\% tepung darah dan diinokulasikan dengan Lactobacillus plantarum dan Bacillus subtilis yang difermentasi selama 21 hari. Fermentasi rapessed meal dan tepung darah menggantikan bungkil kedelai sebesar 0, 33, 67 dan 100\%. Hasil menunjukkan konsumsi pakan itik yang diberi 100\% FRSM lebih baik dibandingkan dengan itik yang diberi pakan bungkil kedelai dan sebagian FRSM (33 dan 67\%). Pertumbuhan harian itik meningkat bertahap pada penggantian bungkil kedelai 33, 67 dan 100\% $(75,9 ; 76,3$; dan $80,1 \mathrm{~g})$, sementara pertumbuhan harian itik yang diberi bungkil kedelai $100 \%$ sebesar 78,1 g. Pemberian fermentasi rapeseed meal dan tepung darah dalam menggantikan $100 \%$ bungkil kedelai $(20 \%$ dalam ransum) menghasilkan performa itik yang hampir sama dengan yang diberi pakan bungkil kedelai. Fermentasi merubah karakteristik fisik dan nutrisi dari rapeseed meal. 
Tabel 1. Penelitian yang terkait dengan pemanfaatan tepung darah sebagai pakan ternak

\begin{tabular}{|c|c|}
\hline Peneliti & Perlakuan \\
\hline 1 & 2 \\
\hline Makinde et al. ( 2011) & $\begin{array}{l}\text { Limbah jagung di campur dengan darah segar } \\
\text { (dicegah dari penggumpalan dengan } \\
\text { menambahkan } 18 \text { g garam/liter) dengan } \\
\text { perbandingan } 1: 1(\mathrm{w} / \mathrm{w}) \text {, campuran dikeringkan } \\
\text { 3-4 jam dan dicampur lagi dengan darah }(5: 4) \\
\text { dan digiling dalam bentuk tepung dan diberikan } \\
\text { pada ayam broiler } 50,100 \text {, dan } 150 / \mathrm{kg} \text { ransum. }\end{array}$ \\
\hline Anoh and Akpet (2013) & $\begin{array}{l}\text { Darah di rebus, lalu dikeringkan dan setelah itu } \\
\text { digiling menjadi tepung. Diberikan pada ayam } \\
\text { broiler untuk menggantikan tepung ikan. } \\
\text { Pemberian } 5 \text { dan } 10 \% \text { yang ditambahkan } 100 \mathrm{~g} \\
\text { enzyme. }\end{array}$ \\
\hline King'ori et al. (1998) & $\begin{array}{l}\text { Perbandingan fermentasi tepung darah dengan } \\
\text { pemasakan tepung darah yang diaplikasikan } \\
\text { terhadap ransum babi. }\end{array}$ \\
\hline Nakhash (2008) & $\begin{array}{l}\text { Darah dipanaskan dalam oven } 60-80^{\circ} \mathrm{C} \text { selama } \\
3-4 \text { jam dan diaduk untuk memudahkan } \\
\text { penguapan air dan penggumpalan. Darah yg } \\
\text { menggumpal dijemur pada sinar matahari } 3-4 \\
\text { hari dan kemudian digiling dalam bentuk } \\
\text { tepung. }\end{array}$ \\
\hline
\end{tabular}

Seifdavati et al. (2008) Pengaruh pakan tepung darah(campuran darah sapi,kambing dan domba) sebagai pengganti 0 , $25,50,75,100 \%$ tepung ikan untuk broiler.

Khawaja et al. (2007) Darah direbus pada suhu $100^{\circ} \mathrm{C}$ selama 45 menit untuk menguapkan air dan membunuh bakteri patogen kemudian di oven pada suhu $55^{\circ} \mathrm{C}$ selama 6 hari dan kemudian digiling dalam bentuk tepung.

Memon et al. (2002) Pemberian tepung darah 0, 3, 4, 5, 6\% yang dicampur dalam ransum.

Esonu et al. (2011)

Darah dan cairan rumen dicampur dengan perbandingan 1:3 dan difermentasi selama 4 hari lalu dikeringkan pada sinar matahari 3-4 hari. Digiling menjadi tepung dan diberikan dalam ransum broiler finisher $0,5,10,15$ dan $20 \%$.

Makinde et al. (2008) Rumen segar dikurangi airnya dengan di press selama 30 menit. Darah segar (dicegah dari penggumpalan dengan memberikan garam $18 \mathrm{~g} /$ liter) dicampur dengan cairan rumen, dikeringkan 3-4 jam, digiling, dicampur lagi dengan darah segar dan digiling lagi kedalam bentuk tepung.diberikan pada broiler 5,10 dan $15 \%$

Odunsi (2003) Darah sapi dan cairan rumen dicampur (1:1), direbus selama 90 menit, dijemur dengan cahaya matahari selama 3 hari sampai kadai air $15 \%$. Diberikan pada ayam petelur 5 dan $10 \%$ menggantikan tepung ikan dan bungkil kacang tanah.

Hasil Penelitian
Tidak ada efek buruk pada
pertumbuhan dengan memasukkan
campuran jeroan jagung dan darah
kering sebagai alternatif untuk
menggantikan tepung ikan, hingga
$150 \mathrm{~g} / \mathrm{kg}$ dalam starter dan finisher
ayam broiler.

Pemberian tepung darah yang disuplementasi enzim pada ransum broiler sampai $10 \%$ tidak menimbulkan efek buruk terhadap performance broiler.

Fermentasi tepung darah lebih tinggi pengaruhnya terhadap performance babi dibandingkan pemasakan tepung darah.

5\% Tepung darah dan 5\% tepung darah dapat ditambahkan dalam ransum broiler tanpa mengalami efek buruk terhadap produksi pada akhir periode pemeliharaan broiler.

Dapat menggantikan tepung ikan $100 \%$

Penggunaan tepung darah sampai 3 $\%$ dapat ditambahkan dalam ransum broiler priode finisher tanpa memiliki pengaruh buruk.

Penggunaan 3\% tepung darah sebagai sumber protein hewani dalam ransum broiler dapat mengurangi biaya produksi.

Penggunaan fermenasi darah sapi dengan cairan rumen sebagai bahan pakan broiler finisher dapat digunakan sampai $20 \%$ dalam ransum.

Campuran cairan rumen dan tepung darah sampai $10 \%$ dalam ransum dapat meningkatkan pertumbuhan broiler dan dapat menggantikan tepung ikan.

Campuran darah sapi dan cairan rumen dapat menggantikan tepung ikan dengan memberikan respon pertumbuhan yang bagus dibandingkan dengan menggantikan bungkil kacang tanah. 
Continued

\begin{tabular}{|c|c|c|}
\hline Peneliti & Perlakuan & Hasil Penelitian \\
\hline 1 & 2 & 3 \\
\hline $\begin{array}{l}\text { Mohammed et al. } \\
\text { (2013) }\end{array}$ & $\begin{array}{l}\text { Campuran darah sapi dan rumen sapi dalam } \\
\text { ransum kelinci sampai level } 40 \% \text { untuk } \\
\text { menggantikan jagung dan bungkil kacang tanah. }\end{array}$ & $\begin{array}{l}\text { Jagung dan bungkil kacang tanah } \\
\text { dapat digantikan dengan campuran } \\
\text { darah sapi dan rumen sapi sebanyak } \\
40 \%\end{array}$ \\
\hline Kats et al. (1994) & $\begin{array}{l}\text { Evaluasi tepung darah kering semprot dalam } \\
\text { ransum babi starter. }\end{array}$ & $\begin{array}{l}\text { Tepung darah kering semprot efektif } \\
\text { sebagai sumber protein untuk } \\
\text { ransum babi stater. }\end{array}$ \\
\hline $\begin{array}{l}\text { Onyimonyi dan Ugwe } \\
\text { (2007) }\end{array}$ & $\begin{array}{l}\text { Darah segar ditimbang dan dicampur dengan } \\
\text { kulit ubi kayu, campuran dipanaskan selama } 30 \\
\text { menit dengan temperatur } 75-85^{\circ} \mathrm{C} \text {, lalu } \\
\text { dikeringkan. Campuran kulit ubi jayu dan darah } \\
\text { yaitu } 1: 1,1: 2,1: 3,2: 1 \text { dan } 3: 1 \text { diberikan pada } \\
\text { ransum ayam broiler. }\end{array}$ & $\begin{array}{l}\text { Campuran kulit ubi kayu dan darah } \\
\text { sapi dalam berbagai level mendu- } \\
\text { kung pertumbuhan yang efektif } \\
\text { tetapi combinasi } 1: 3 \text { memberikan } \\
\text { keuntungan ekonomi yang optimum. }\end{array}$ \\
\hline Xu et al. (2011) & $\begin{array}{l}70 \% \text { rapessed meal dan } 25 \% \text { tepung darah } \\
\text { dicampur dan dinokulasikan dengan } \\
\text { Lactobacillus plantarum dan Bacillus subtilis } \\
6 \% \text {, difermentasi selama } 3 \text { minggu dalam } \\
\text { kondisi anaerob, dikeringkan } 50-60^{\circ} \mathrm{C} \text { selama } 3 \\
\text { hari. Untuk menggantikan bungkil kedelai }\end{array}$ & $\begin{array}{l}\text { Rapeseed meal fermentasi dengan } \\
\text { Lactobacillus plantarum dan Bacilus } \\
\text { subtilis menjadi alternatif sumber } \\
\text { protein dan dapat menggantikan } \\
\text { bungkil kedelai pada ransum itik. }\end{array}$ \\
\hline
\end{tabular}

Ekunseitan et al. (2013)

Setiowati et al

DeRouchey et al. (2002)

Balagun (1982)

Namgung et al. (2010)

Habib et al. (2009) hari. Untuk menggantikan bungkil kedelai 0,33,67 dan 100 dalam ransum itik.

P1=Limbah sayur, darah segar, dan rumen dicampur kemudian dikeringkan. P2=darah segar diselase selama 3 hari dicampur dengan limbah sayur dan rumen segar. P3=rumen disilase selama 3 hari dicampur dengan limbah sayur dan darah segar. Diberikan pada ayam 0,3 dan $6 \%$.

Darah segar direbus selama 20 menit dengan suhu $80^{\circ} \mathrm{C}$, dijebur dibawah sinar matahari dengan ketebalan $1 \mathrm{~cm}$ selama 16 jam. Dioven dalam suhu $60^{\circ} \mathrm{C} \quad 2-3$ hari, digiling hingga menjadi tepung. Diberikan 4, 8 dan 12\% dalam ransum puyuh.

Membandingkan pertumbuhan babi lepas sapih dengan peningkatan level tepung darah dan pengukuran ketersediaan lisin dari tepung darah kering semprot.

Darah segar dipanaskan sampai mendidih kemudian dikeringkan. Diberikan pada pakan babi.

Tepung darah kering semprot dari darah babi untuk menentukan apakah tepung darah dan $\mathrm{MgO}$ dapat berpengaruh terhadap kadar LCarnosine dalam otot dada ayam petelur.

Darah segar dicampur kedalam air minum sebanyak $0.25,0.50,0.75 \mathrm{~g} /$ liter untuk performa broiler.
Ransum P3 sampai 6\% dapat meningkatkan performa dan mengurangi kolesterol broiler.

Penambahan tepung darah 4,8 , dan $12 \%$ significan meningkatkan persentasi karkas.

Penambahan tepung darah kering semprot menguntungkan untuk pertumbuhan sapi dari hari ke 5-12 setalah lepas sapih.

Babi yang diberi tepung darah cendrung tumbuh cepat, banyak konsumsi dan sedikit lebih efisien dibandingkan yg tidak diberi tepung darah.

Secara umum penambahan tepung darah dan $\mathrm{MgO}$ tidak berpengaruh terhadap kadar L-Carnosine dalam otot dada, namun tepung darah $5 \%$ dan $\mathrm{MgO}$ menunjukkan tingginya kadar L-Carnosine.

Darah significan meningkatkan pertumbuhan dan konversi. Tepung darah $0,25 \mathrm{~g} / \mathrm{l}$ dapat digunakan dalam air minum selama fase growing dan fisher broiler untuk meningkatkan performa. 


\begin{tabular}{|c|c|c|}
\hline ontinued & & \\
\hline Peneliti & Perlakuan & Hasil Penelitian \\
\hline 1 & 2 & 3 \\
\hline Olabanji et al. (2007) & $\begin{array}{l}\text { Bunga matahari dan tepung darah dicampur } \\
\text { dengan perbandingan 2:1. Campuran diberikan } \\
0,5,10 \text { dan } 20 \% \text { dalam ransum kelinci sapih. }\end{array}$ & $\begin{array}{l}\text { Campuran bunga matahari dan } \\
\text { tepung ikan dapat dimanfaatkan dan } \\
\text { toleran terhadapa kelinci lepas sapih } \\
\text { sampai } 20 \% \text { tanpa menyebabkan } \\
\text { pengaruh negatif terhadap pertum- } \\
\text { buhan. }\end{array}$ \\
\hline Usman et al. (2007) & $\begin{array}{l}\text { Darah segar dicampur dengan } 1: 1 \text { propionat dan } \\
\text { asam formic, dicampur sebayak } 3 \% \text { dari total } \\
\text { darah, fermentasi selama } 5 \text { hari, dikeringkan } \\
\text { dan digiling menjadi tepung. Digunakan untuk } \\
\text { pakan ikan tiger grouper }\end{array}$ & $\begin{array}{l}\text { Penambahan fermentasi tepung } \\
\text { darah kurang dari } 9 \% \text { tidak menim- } \\
\text { bulkan pengaruh buruk, namun } \\
\text { penambahan lebih dari } 9 \% \\
\text { menyebabkan penurunan pertumbu- } \\
\text { han ikan Tiger grouper. }\end{array}$ \\
\hline $\begin{array}{l}\text { Bekibele dan Oruwari } \\
\text { (2012) }\end{array}$ & $\begin{array}{l}\text { Darah segar dan dedak gandum dicampur } \\
\text { dengan perbandingan } 2: 1 \text { dan } 1: 1 \text { dicampur } \\
\text { dengan minyak kelapa sawit dan dikeringkan. } \\
\text { Diberikan pada broiler finisher. }\end{array}$ & $\begin{array}{l}\text { Minyak kelapa sawit bisa efektif } \\
\text { dikombinasikan dengan dedak gan- } \\
\text { dum untuk menyediakan keseim- } \\
\text { bangan energi ketiga digunakan } \\
\text { dengan tepung darah sebagai pakan } \\
\text { broiler finisher. }\end{array}$ \\
\hline
\end{tabular}

Protein kasar dan lemak kasar meningkat setelah fermentasi, dimana peningkatan protein mungkin dikarenakan penurunan sebagian dari karbohidrat setelah fermentasi ( $\mathrm{Xu}$ et al., 2011). Vig dan Walia (2001) juga menyatakan fermentasi dapat meningkatkan kadar nitrogen dan protein rapessed meal.

Menurut Wizna et al. (2014), fermentasi campuran dedak padi dan darah dengan $B$. amyloliquefaciens yang terbaik pada dosis inokulum 3\% dan lama fermentasi 3 hari dengan kenaikan protein kasar dari 41,02\% menjadi $56,28 \%$, retensi nitrogen dari $26,90 \%$ menjadi $64,07 \%$, menurunkan serat kasar $38,38 \%$ (dari $11,27 \%$ menjadi $7,17 \%$ ), meningkatkan kecernaan SK 23,46\% $(36,42 \%-47,58 \%)$ dan meningkatkan EM $12,36 \%$ (2956-3373 kal/gram).

\section{Pengaruh pemberian tepung darah terhadap performa unggas}

Pemberian tepung darah di dalam ransum unggas telah banyak diterapkan dalam berbagai penelitian yang digunakan sebagai sumber protein pengganti tepung ikan maupun bungkil kedelai. Tepung ikan dan bungkil kedelai merupakan bahan pakan penyusun ransum unggas yang sangat penting karena memiliki protein tinggi dan kandungan asam amino yang bagus tetapi harganya yang tinggi menyebabkan meningkatkan biaya produksi sehingga perlu dicari bahan pakan pengganti sumber protein yang lebih murah dan ketersediaannya tidak bersaing dengan kebutuhan manusia. Peran nutrisi untuk produksi broiler adalah sama pentingnya dengan managemen atau ternak itu sendiri, tapi konstribusinya melampaui aspek yang lainnya. Nutrisi yang bagus memiliki peran yang significant terhadap produksi yang optimal (NRC, 1984).

Khawaja et al. (2007) melaporkan pemberian tepung darah sebanyak 3\% dalam ransum ayam broiler tidak menimbulkan pengaruh yang negatif terhadap performa pada broiler starter dan finisher namun semakin meningkat pemberian tepung darah akan mengurangi berat badan broiler, hal ini dikarenakan rendahnya asam amino sulfur dan isoleusin pada tepung darah (Onwudike, 1981). Pada penelitian ini mencampurkan 3\% tepung darah dengan $8-10 \%$ tepung ikan dan $1 \%$ tepung kedelai untuk mendapatkan kombinasi asam amino terbaik dalam ransum. Hassan et al. (1974) melaporkan pemberian $6 \%$ tepung darah dengan $15 \%$ tepung daging dapat digunakan dalam ransum broiler tanpa menyebabkan pengaruh buruk terhadap pertumbuhan broiler.

Memon et al. (2002) menggunakan tepung darah sebesar 3\% sebagai sumber protein yang memberikan hasil pertumbuhan dan karkas yang bagus. Seifdavati et al. 
(2008) menggunakan tepung darah sebagai pengganti tepung ikan dalam ransum broiler, dalam percobaan ini tepung ikan digantikan dengan tepung darah sebanyak $0,25,50,75$ dan $100 \%$ yang mana penggantian tepung ikan sebanyak 75\% dapat meningkatkan berat akhir broiler, tetapi interaksi antara perlakuan berbeda tidak nyata. Sifat fungsional dari tepung darah dan sumber protein hewani lainnya yaitu berdasarkan konsentrasi protein yang umumnya tergantung pada kadar protein dan kualitanya (Sujeewa, 2000).

Pemberian tepung darah tidak hanya dilakukan dengan mencampurkannya dalam ransum. Habib et al. (2009) melakukan pemberian tepung darah melalui air minum, mereka mencampurkan tepung darah kedalam air minum sebanyak $0 ; 0,25(2,5 \%) ; 0,50$ $(5,0 \%)$ dan $0,75(7,5 \%)$ per liter air minum yang diberikan setiap hari dimana pemberian tepung darah sebanyak 2,5\% dalam air minum significant meningkatkan pertumbuhan broiler. Penambahan tepung darah menghasilkan peningkatan yang significant terhadap tingkat pertumbuhan dan berat badan yang lebih baik (Toor dan Ullah, 1972).

Pemanfaatan tepung darah sebagai sumber protein tidak hanya digunakan dalam ransum ayam. Djaya (2010) melakukan penelitian untuk mengetahui pengaruh tepung darah dalam ransum burung puyuh dimana perlakuan tepung darah sebanyak $5 \%$ mencapai nilai tertinggi yang meliputi konsumsi pakan $(77,52$ g/ekor), pertambahan berat badan (65,13 g/ekor) dan berat badan akhir $(80,25$ g/ekor) serta konversi ransum yang terendah sebesar $(1,19)$. Penggunaan tepung darah melebihi $5 \%$ dalam ransum akan menyebabkan zat nutrien di dalam ransum tidak tercerna dengan baik. Hal ini sesuai dengan pernyataan Rasyaf (1994a) bahwa penggunaan tepung darah yang terlalu tinggi akan menghambat proses kecernaan bahan pakan lainnya dalam tubuh yang disebabkan keterbatasan isoleusin yang pada tepung darah.

\section{Pengaruh pemberian tepung darah pada ternak non ruminansia}

Pemanfaatan tepung darah sebagai bahan pakan sumber protein tidak hanya digunakan sebagai bahan pakan penyusun ransum unggas, tetapi juga telah banyak digunakan sebagai bahan pakan penyusun ransum ternak non ruminansia seperti kelinci dan babi. Pada ternak kelinci, Mohammed et al. (2013) melakukan evaluasi kecernaan nutrisi dan mengukur pertumbuhan karkas dari kelinci yang diberi pakan campuran darah sapi dan cairan rumen sampai $40 \%$ dalam ransum menggantikan jagung dan bungkil kacang tanah dimana didapatkan hasil ransum yang mengandung campuran darah sapi dan cairan rumen dapat menggantikan jagung dan bungkil kacang tanah dalam ransum kelinci sampai $40 \%$ tanpa mempengaruhi kecernaan nutrisi dan pertumbuhan karkas. Fetuga et al. (1974) melaporkan protein tepung darah lebih baik dibandingkan dengan protein tumbuhan dan lebih tinggi kandungan asam amino lysine dan leucine. Olabanji et al. (2007) juga telah melaporkan pengaruh level dari campuran daun bunga matahari dan tepung darah dengan rasio 2:1 terhadap pertumbuhan kelinci lepas sapih, 4 ransum diformulasikan mengandung 0\% (kontrol); 5; 10 dan 20\% campuran daun bunga matahari dan tepung darah. Ransum yang mengandung $20 \%$ campuran daun bunga matahari dan tepung darah efisien digunakan dan toleran oleh kelinci lepas sapih.

Balogun (1982) meneliti tentang tentang pengaruh level protein kasar dan suplementasi tepung darah dalam ransum terhadap babi grower. Perlakuan dari percobaan yang dilakukan oleh Balogun yaitu dengan memberikan ransum dengan komposisi protein sebesar 18 , 20,22 dan $24 \%$ dengan atau tanpa suplementasi tepung darah. Perbandingan suplementasi tepung darah dan bungkil kacang tanah dalam ransum sebesar 1:4. Pada level protein $18,20,22$, dan $24 \%$ mengandung tepung darah masing-masing sebesar $4 ; 4,8$; 5,67 dan $6,6 \%$. Nilai tertinggi dari persentase kecernaan apparent nitrogen dan retensi nitrogen yaitu pada level protein $22 \%$ yang 
mengandung tepung darah sebesar 5,67\%. Peningkatan performa dari ransum yang mengandung tepung darah dikarenakan pengaruh dari kandungan lysine dari tepung darah, dimana bungkil kacang tanah memiliki kandungan lysine yang terbatas (Brooks dan Thomas 1959).

\section{KESIMPULAN}

Metode pengolahan tepung darah pada umumnya menggunakan metode pengeringan, penyerapan dan fermentasi. Pengolahan tepung darah dengan metode penyerapan terbukti dapat meningkatkan pemanfaatan tepung darah sampai $15 \%$ dalam ransum unggas, sedangkan metode pengeringan hanya dapat memanfaatkan tepung darah sekitar 3$6 \%$ dalam ransum unggas. Metode penyerapan ini juga dapat dimodifikasi dengan fermentasi menggunakan mikroorganisme sebagai inokulum. Pemanfaatan tepung darah dengan metode penyerapan yang dikombinasikan dengan fermentasi dapat meningkatkan penggunaan tepung darah sebagai pakan unggas mencapai $20 \%$ dalam ransum.

\section{DAFTAR PUSTAKA}

Abubakar, M. M and A. O. Yusuph. 1991. Efectiveness of rumen content in poultry rations. Nig. J. Anim. Prod. Proceedings 16th Annual Conf. P:78-79.

Anoh, K. U. and S. O. Akpet. 2013. Growth response of broiler chickens fed diets containing blood meal with enzyme supplementation as a replacement for fish meal. Journal of Agriculture and Veterinary Science. Pp 31-34.

Balogun, T. F. 1982. The effect of dietary protein level and blood meal supplementation on the performance of growing large white and landrage pigs in Nigeria. Tropical Animal Production. 7: 14-19.

Bekibele, D. O and B. M Oruwari. 2012. The impact of palm oil on the combination of blood meal and wheat brain in diet for broiler finisher. J. Agricultural Science. 6 (3): 8-15.

Cheng, S.W., Y. F. Wang, and M.L. Wang. 2012. Statistical optimization of medium compositions for alkaline protease production by newly isolated bacillus amyloliquefaciens. Chem.. Biochem. Eng. Q. 26 (3): 225-231.

Cho, S. J. 2009. Isolation and characterization of mannanase producing Bacillus amyloliquefaciens CS47 from horse feces. Journal of Live Science 200919. (12): 1724-1730.

Crawshaw, R. 1994. Blood Meal: a review of its nutritional qualities for pig, poultry and ruminant animals. National Renderers Association Tecnical Review. United Kingdom. (594) 7.

Dafwang, I. I., J. M Olomu, S.A. Offiong. dan S. A Bello. 1986. The effect of replacing fish meal with blood meal in the diets of laying vhickens. Journal of Animal Production Research. (6) 81-92.

Das, M. P., L. R Jeyanthi, S. Sharmila, Anu, B Ankita, and Dhiraj Kumar. 2012. Identification and optimization of cultural condition for chitinase production by Bacillus amyloliquefaciens SM3. Jurnal of Chemical and Pharmaceutical Research. 2012, 4(11):4816-4821.

Deb, P., S.A Talukdar, K Moshina, P.K Sarker, and S.M.A Sayem. 2013. Production and partial characterization of extracellular amylase enzyme from Bacillus amyloliquefaciens P-001. Springer Plus. 2:154.

DeRouvhey, J. M., M. D. Tokach, J. L. Nelssen, R. D. Goodband, S. S. Dritz, J. C. Woodworth, and B. W. James. 2002. Comparison of spray-dried blood meal and blood cells in diets for nursey pigs. J. Anim. Sci. 80: 2879-2886.

Djaya, M. S. 2010. Pengaruh penggunaan tepung darah dalam ransum terhadap 
penampilan burung puyuh. Media Sains. (2).

Dongmo, T., J. D. Ngou Ngoupayou and M. Pouilles Dupoix. 2000. Use of some local animal protein sources in the feeding of broilers. Tropicultura. 18: 122-125.

Donkoh, A., C.C. Atuahene., D.M. Anang and S.K. Ofori. 1999. Chemical composition of solar-dried blood meal and its effect on performance of broiler chickens. Animal Feed Science and Technology 81: $299-307$.

Ekunseitan, D.A., Balogun, O.O., Songule, A.M., Yusuf, A.O., Ayoola, A.A., Egbeyale, L.T., Adeyemi, O.A., Allison, I. B. Dan Iyanda, A. I. 2013. Healts status of birds fed diets containing three differently processed discarded vegetable-bovine blood-rumen content mixture. Pakistan Journal of Biological Science. 16 (7): 325-331.

Ekwuoma, C. 1992. The chemical composition of ruminal contents of cattle, sheep and goat. B.Sc Project Report University of Agriculture. Abeokuta Nigeria.

Emmanuel, B. 1978. Effects of rumen contents or fraction there on performance of broiler. Br. Poult. Sci. 19: $13-16$.

Esonu, B. O., U. D. Ogbonna, G. A. Anyanwu and O. O. Emenalom. 2006. Evaluation of performance, organ characteristics and economic analysis of broiler finisher fed rumen digesta. Inter. Journal of Poultry Science. 5 (2): 1116-1118.

Esonu, B.O., Azubuike, J.C., A.B Udedibie, I., O.O Emenalom, T.C Iwuji and V Odoemenam. 2011. Evaluation of the nutritive value of mixture of fermented bovine blood and rumen digesta for broiler finisher. Journal of Natural Sciences Reesearch. Vol. 1, No.4.

Fetuga, B.L., G.M. Babatunde, V.A. Oyenuga. 1974. Comparative assessment of the supplementary value of maize of some Nigerian protein concentrates with young pigs. Nig. J. Sci. 8: 37-44.

Gangadharan, D., S. Sivaramakrishman, K.M Nampoothiri, and A. Pandey. 2006. Solid culturing of bacillus amyloliquefaciens for alpha amylase production. Food Technol. Biotechnol. 44(2) 269-274.

Gul, A., F. Kidoglu, Y. Tuzel and I. H. Tuzel. 2008. Effects of nutritions and Bacillus amyloliquefaciens on tomato (Salanum lycopercium L.) growing in perlite. Spanish Journal of Agricultural Research. 6 (3), 422-429.

Habib, M. A., M. Shahidullah and M.A Ali. 2009. Performance of broiler fed watersoluble blood meal during growing and finishing period. The Bangladesh Veterinarian. 26 (1): 8-12.

Hassan O.E.M., A.M.S. Mukhtar and M.E.A. Nasir. 1974. The use of blood meal in tropical broiler diets. Top. Anim. Health Prod. 6: 179-182.

Horniakova, E. 2005. The influence of Enterococus faecium N-74 bacteria on bone mineralization in chickens. In proceedings of 15th European Symposium on Poultry Nutrition. Balotonfured. Hungary. Pp. 195-197.

Hurrel, R. F. 1990. Influence of the mailard reaction on nutritional foods. In: the Maillard reaction in food processing, nutrition and physiology. Birkhauser Verlag. Basel. Switzerland. Pp: 245-258.

Ibrahim, A.D., Mukhtar, I. Sa'adat, M.N Ibrahim, M.A Oke. and A.K Ajijolakewu. 2012. Adonsonia digitata (Baobab) fruit pulp as substrate for Bacillus Endoglucanase production.

Kats, L.J., J.L. Nelsen, M.D. Tokach, R.D. Goodband, T.L. Weeden, S .S. Dritz, J. A. Hansen and K. G. Friesen. 1994. The effects of spray-dried blood meal on 
growth performance of the early-weaned pig. J. Anim. Sci. 72: 2860-2869.

Khawaja T., S.H Khan and N.N Ansari. 2007. Effect of different leevels of blood meal on broiler performance during two phases of growth. International Journal of Poltry Science. 6 (12): 860-865.

Kim, Y.O., J.K. Lee. H.K. Kim, J.H. Yu and T.K. Oh. 1998. Cloning of the thermostable phytase gene (phy) from Bacillus sp. DS11 and its overexpression in Escherichia coli. FEMS Microbiol. Lett., 162: 185-191.

King' Ori, A.M., J.K. Tuitoek and H.K. Muirari. 1998. Comparison of fermented dried blood meal and cooked dried blood meal as protein suplements for growing pigs. J. Trop. Anim. Health. Prod. 30 : 191-196.

Luizmeira.Com/enzimas.htm. USB Recomendar esta pagina. 2005.

Mabrouk, M.E.M. and M.D Amani. El Ahwany. 2008. Production of $\beta$ mannanase by Bacillus amyloliquefaciens 10A1 cultured on potato peels. African journal of Biotechnology 7 (8): pp. 1123-1128.

Makinde, O.A. and EB Sonaiya. 2007. Determination of water, blood and rumen fluid absorbencies of some fibrous feedstuffs. Jurnal Livestock for rural development 19 (10) 2007.

Makinde, O.A. and EB Sonaiya. 2011. Utilization of sun-dried maize offal with blood meal in diets for broiler chickens. Journal of Animal Sciences. 1. (3): 106111.

McDonald, P. Edward, J.F.D Greenhalgh. 1992. Animal Nutrition. $4^{\text {th }}$ ed. Published in the United States with John Wiley and Sons. Inc. New York pp. 455483.

McDonald, P., R.A Edward, J.F.D Greenhalgh, and C.A Morgan. 1998. Animal Nutrition. Longman Publishers.
Memon, A., N.N Ansari, A.A Solangi and G. Memon. 2002. Effect of blood meal on the growth and carcass yield of broiler. Pakistan Vet J. 22 (3).

Mohammed, G., S.B Adamu, J. Igwebuike, N.K Alade and Asheikh. 2013. Nutrient digestibility and carcass measurement of growing rabbits fed graded levels ov bovine blood-meal content mixture. Pakistan Journal of Nutrition. 12 (10): 929-933.

Namgung, N., D.H. Shin, S. W. Park, and I.K. Paik. 2010. Effects of supplementary blood meal on carnosine content in the breast meay and laying performance of old hens. J. Anim. Sci. Vol. 23, No. 7: 946-951.

Ningsih, D. R., U. Rastuti, R. Kamaludin. 2012. Karakteristik enzim amilase dari bakteri Bacillus amyloliquefaciens. Prosiding Seminar Nasional.

Njoku, P.C. 1985. Performance of broiler chickens fed graded levels of blood meal. Nig. J. Animm Prod. 12: 69-73.

NRC. 1994. Nutrient Requirement for Poultry. $9^{\text {th }}$ Ed. National Academy Press. Washington D.C. U.S.A.

Nursten, H. 2005. The Maillard Reaction. Chemistry, Biochemistry, and Implications. Royal Society of Chemistry, Cambridge, UK.

Odukwu, C.A. and P.C. Njoku. 1987. Evaluation of Blood Meal and its Potential as a Supplementary source pf lysine in laying chicken diets. J. Anim. Prod. Res. 7: 9-18.

Odunsi, A. A. 2003. Blend of bovine blood and rumen digesta as a replacement for fishmeal anf groundnut cake in layer diets. International Journal of Poultry Science. 2 (1): 58-61.

Okorie, K. C. 2005. The effects of dried pulverized rumen content on the performance, carcas and organ 
characteristic of broiler finisher. Anim. Prod. Res. Adv. 2:96-100.

Oktavia, D. 2007. Kajian SNI 01-2886-2000 Makanan Ringan Ekstrudat. Jurnal Standarisasi 9 (1).

Olabanji, R. O., G.O Farinu, J.A Akinlade and O.O Ojebeyi. 2007. Growth performance, organ characteristics and carcas quality of weaner rabbits fed differents levels of wild sunflower (Tithonia diversifolia Hemsi A. Gray) leaf-blood meal mixture. International Journal of Agricultural Research. 2 (12): 1014-1021.

Onyimonyi, A. E. dan S. O. C. Ugwu. 2007. Bioeconomic indices of broiler chicks fed varying rations of cassava peel/bovine blood. International Journal of Poultry Science. 6 (5): 318-321.

Onwudike, O.C. 1981. Effect of various protein sources on egg production in a tropical environment. Trop. Anim. Prod. 6: 249-256.

Padmono, D. 2005. Alternatif pengolahan limbah rumah potong hewan - Cakung (suatu studi kasus). J. Tek. Lingk. P3TL. - BPPT. 6 (1): 303-310.

Pahm, A.A., C. Pedersen, and H.H. Stein. 2008. Application of the reactive lysine procedure to estimate lysine digestibility in distillers dried grains with solubles fed to growing pigs. J. Agric. Food Chem. 56:9441-9446.

Priest, F.G., M. Goodfellow, L.A Shute \& R.C.W. Berkeley. 1987. Bacillus amyloliquefaciens sp. nov., nom. rev. Int J Syst Bacteriol 37, 69-71.

Rasyaf, M., 1994a. Memelihara Burung Puyuh. Kanisius. Yogyakarta.

Saban, M.T., and D. Ozer. 2011. An investigation of $\alpha$-amylase production in semi solid substrate fermentation by using corn bran with bacillus amyloliquefaciens. Turkish Journal of Science \& Technologi. 6. (1), 47-52.
Saha, K., S. Maity, S. Roy, K. Pahan, R. Pathak, S. Majumdar, and Gupta, S., 2014. Optimization of amylase production from Bacillus amyloliquefaciens (MTCC 1270) using solid state fermentation. International Journal of Microbiology. 2014, Article ID 764046, 7 pages.

Seivdavati, J., B. Navidshad, R. Seyedsharifi, and A. Sobhani. 2008. Effects of locally produced blood meal on performance, carcass traits and nitrogen retention of broiler chickens. Pakistan Journak of Biological Sciences. 11 (12): 16251629.

Selvamohan, T., V. Ramadas and T.A Sathya. 2012. Optimization of lipase enzyme activity produced by Bacillus amyloliquefaciens isolated from rock lobster Panlirus Homareus. International Journal of Modern Enginering Reserch (IJMER).

Setiowati S., E. Sudjarwo and A.A Hamiyanti. 2014. The effect of blood meal addition in the feed to carcass and giblet percentages of quail.

Sharma, N., R. Vamil, R. Agarawal, S. Bhooshan. 2012. An investigation of $\alpha$ amylase production in submerged fermentation by Bacillus amyloliquefaciens. Journal of Pharmacy Reserch 2012, 5(7) : 3548-3550.

Shrimp Culture Biotechnology Reserch Center.http://shrimp-biotek.com/index. php?option=com_content $\&$ view $=$ article $\& \mathrm{id}=48 \&$ Itemid $=56$.

Singh, S., S. Vijayanand and Moholkar. 2014. Optimization of carboxymethylcellulase production from Bacillus amyloliquefaciens SS35. 3 Biotech 4: 411-424.

Sivaramareddy, A., P. Srihari, and D. Kezia. 2014. Assortment of vital nutrients for enhancment of cyclodextrin glycosyl transferase produced by Bacillus amyloliquefaciens K5T5: A Plackett- 
Burman design approach. Journal of Pharmacy Research. 8 (9), 1191-1197.

Sonaiya, E. B. 1988. Animal by-products and their potential for comencial livestock feed production. In: Babatunde G. M., proceedings of a national workshop on alternative feeds in Nigeria. ARMTI. Ilorin. Kwara State. Nigeria. 298-315.

Stoker, H. Stephen. 2010. General, Organic, And Biol

Sujeewa, A. 2000. The evaluation of functional properties of fishmeal. Final Project 120. Skulagata 4. 120 reykjavik. Iceland.

Sukara Dan, E. and A.H. Atmowidjojo. 1980. Pemanfaatan ubi kayu untuk produksi enzim amilase dan protein sel tunggal. Optimasisasi nutrisi untuk proses fermentasi substrat cair dengan menggunakan kapang Rhizopus. Proc. Seminar Nasional. UPT ERG, Lampung.

Sulaiman. 1988. Studi proses pembuatan protein mikroba dengan ragi amilolitik dan ragi simbe pada media padat dengan bahan ubi kayu (Manihot Utilisima Pohl). Thesis Fakultas Teknik Pertanian IPB.

Titin, K. 2011. Potensi tepung darah sebagai sumber protein pakan ikan alternatif. Prosiding Forum Inovasi Teknologi Akuakultur. 1001-1008.

Toor, A.A. and Fahimullah. 1972. Effect of different levels of blood meal on the performance of broiler chick. MSc Thesis. Department of Poultry Husbandry. University of Agriculture. Faisalabad. Pakistan.

Usman, Kamaruddin, Palinggi, N.N, Rachmansyah, and Ahmad T. 2007.
Fermented blood meal use for tiger grouper, Epinephelus fuscoguttatus grow-out diet. Indonesian Aquaculture Journal. 2, (1).

Vig, A. P. and Walia 2001. Beneficial effects of Rhizopus oligosporus fermentation on reduction of glucosinolates, fibre ans phytic acid in rapeseed (Brassica napus) meal. Bioresour. Technol. 78:309-312.

Whyte, P. and Wadak. 2002. Evaluation of rumen content on the growth performance of weaner rabbits. Proc. 7th Annual Conference of Anim. Sci. Asso. Of Nigeria (ASSAN) Sept. 16-19, 2002. University of Agriculture. Abeokuta. Nigeria, pp. 143-146.

Wizna, H. Muis, Jafrinur. 2014. Improving the quality of rice bran and blood mixture as poultry feed through fermentation by Bacillus amyloliquefaciens. Proc. The Inaugural Asian Conference on the Life Sciences and Sustainability, Hiroshima Jepang.

Xu, F., Li, L., Xu, J., Qian, K., Zhang, Z. and Liang, Z. 2011. Effect of fermented rapessed meal on growt performance and serum parameters in ducks. AsianAust. J.Anim. Sci. 24 (5): 678-684.

Yuanhao, H., Xu, J., Wang, S., Zhou, G., and Liu, J. 2014. Optimization of medium component for production of chitin deacetylase by Bacillus amyloliquefaciens $\mathrm{Z7}$, using response surface methodology. Biotechnology \& Biotechnological Equipment. 28, (2): 242-247.

Zhang, Y. and C. M. Parsons. 1994. Effect of over process nutritional quality of sunflower meal. Poult. Sci. 73: 436-442. 